\title{
Will mesenchymal stem cells be future directions for treating radiation-induced skin injury?
}

\author{
Zhuoqun Fang, Penghong Chen, Shijie Tang, Aizhen Chen, Chaoyu Zhang, Guohao Peng, Ming Li and \\ Xiaosong Chen ${ }^{*}$ (D)
}

\begin{abstract}
Radiation-induced skin injury (RISI) is one of the common serious side effects of radiotherapy (RT) for patients with malignant tumors. Mesenchymal stem cells (MSCs) are applied to RISI repair in some clinical cases series except some traditional options. Though direct replacement of damaged cells may be achieved through differentiation capacity of MSCs, more recent data indicate that various cytokines and chemokines secreted by MSCs are involved in synergetic therapy of RISI by anti-inflammatory, immunomodulation, antioxidant, revascularization, and antiapoptotic activity. In this paper, we not only discussed different sources of MSCs on the treatment of RISI both in preclinical studies and clinical trials, but also summarized the applications and mechanisms of MSCs in other related regenerative fields.
\end{abstract}

Keywords: Mesenchymal stem cells, Radiation, Radiotherapy, Skin injury, Treatment

\section{Introduction}

Radiation-induced skin injury (RISI) is a common side effect of radiotherapy (RT) for malignant tumors or bone marrow transplant. Seventy percent of cancer patients especially with head and neck, skin, anogenital, and breast cancer would receive RT alone or as an adjuvant to surgeries at different stages and almost $95 \%$ patients with RT would occur with RISI $[1,2]$.

RISI is divided into acute RISI (occurring within hours to weeks after radiation) with clinical manifestations of skin erythema, blister, dermatitis, and necrotic ulcer and chronic RISI (occurrence from months to years postradiation) with clinical syndromes of fibrosis, leathery skin, atrophy, and pigmentation [3]. These clinical symptoms mentioned above would not only reduce quality of life, but also interrupt tumor treatment progress (Fig. 1). Though traditional methods including topical steroids,

\footnotetext{
* Correspondence: chenxiaosong74@163.com

Department of Plastic Surgery, Fujian Medical University Union Hospital, 29 Xinquan Road, Fuzhou 350001, Fujian, People's Republic of China
}

creams, ointments, and hydrogel dressings have been applied to treat RISI, no criterion standard exists for the treatment of RISI [4-6].

In this paper, we discussed the applications and potential mechanisms of MSCs in RISI and summarized the applications of MSCs in other regenerative fields.

\section{The mechanism of RISI}

The mechanisms involved in RISI include oxidative stress and inflammation. The specific mechanisms of RISI are not fully understood but may be related to DNA damage, changes in cell cycle progression, and/or cell death $[7,8]$. Chemical bond of DNA is particularly vulnerable to break while directly be exposed to radiation and the DNA double-strand breaks (DSBs) are the most serious type of DNA damage, from which $\gamma-\mathrm{H} 2 \mathrm{AX}$ and MRN complex contains Mre11 are early indexes to reflect DNA damage and summarized in Fig. 2 [9-11]. 

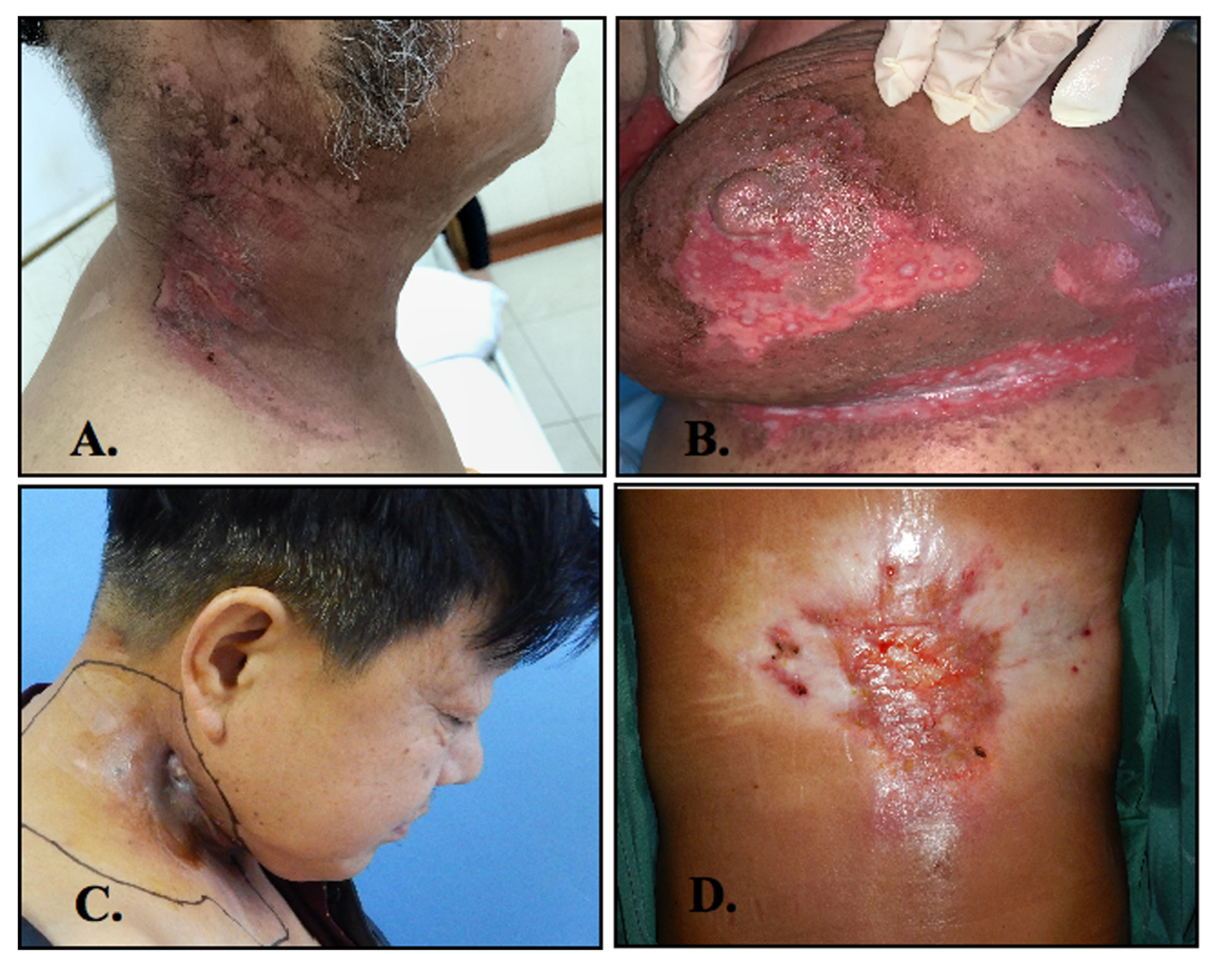

Fig. 1 Four typical cases of radiation-induced skin injury. a Radiation-induced dermatitis appeared in a 61-year-old female patient who was diagnosed with esophageal cancer (T3NOMO) after the third RT. b Radiation-induced dermatitis appeared in a 59-year-old female patient suffering from mammary cancer (T1NOMO) after four times of RT. c Radiation-induced skin ulcer appeared in a 57-year-old male patient who suffered from esophageal cancer (T4NOMO) after 9 times of RT and conventional dressing change. $\mathbf{d}$ Radiation-induced skin ulcer appeared in a 44-year-old male patient with diagnosis of mycosis fungoides after 6 times of RT together with conventional dressing change

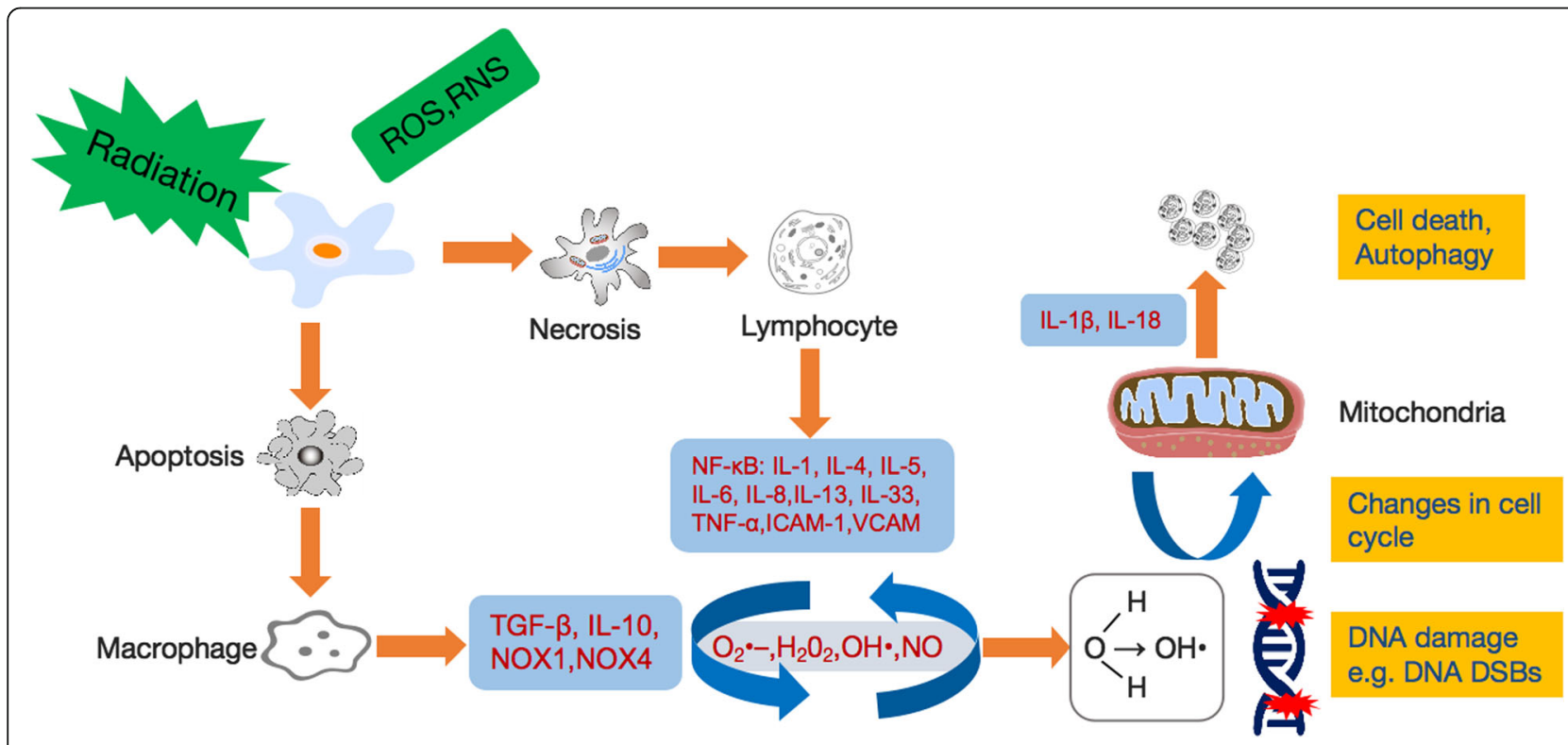

Fig. 2 The molecular mechanisms of RISI 


\section{Oxidative stress}

Oxidative stress is the combination of cell damage and stress response signals that has been taken into account as one of the causes of acute and chronic radiation damage to the body. Reactive oxygen species (ROS) are additional products of aerobic metabolism varieties [10, 11]. Active oxygen-containing metabolites include superoxide anions $\left(\mathrm{O}_{2} \bullet-\right)$, hydrogen peroxide $\left(\mathrm{H}_{2} \mathrm{O}_{2}\right)$, hydroxyl radicals $(\mathrm{OH} \bullet)$, nitric oxide $(\mathrm{NO})$, and its free radicals produced by its reaction with superoxide or oxygen that are known as reactive nitrogen species (RNS) [12-14]. Many reactions mediated by ROS protect cells from oxidative stress and then re-establish "redox homeostasis". The increase of glutathione, an intracellular antioxidant, or the increase of protein/enzyme expression ability of scavenging ROS in cells is called oxidative stress reaction to maintain redox homeostasis in cells and tissues [15-17].

Some studies show that radiation damage to a single cell could trigger some signals and amplify the production of free radicals in irradiated cells that last for hours to days or even months $[18,19]$. In addition, signals generated by irradiated cells could also be transferred to neighboring non-irradiated cells through bystander effects and activate REDOX metabolism [20]. Cytokines, miRNAs, vesicles, high mobility group box 1 (HMGB1), and free DNA fragments are those intracellular mediators by which chronic ROS/RNS released from irradiated cells, resulting in cell damage [21-23].

\section{Inflammation}

ROS/RNS could injure biological molecules such as nucleic acids, proteins, and lipids which would trigger a series of inflammatory reactions, result in apoptosis, and inhibit cell proliferation [24, 25]. Epithelial cells are extremely sensitive and susceptible to radiation as well as blood vessel and cutaneous appendages [26]. Free radicals generated from the interaction between radiation and water molecules may cause damage to biologically active ingredients. In the early stage of radiation injury, epithelial dysplasia, cell necrosis, nuclear pyknosis, and tissue fibrosis could be observed under the microscope $[27,28]$. What is more, DNA DSBs caused by radiation would trigger changes in cell cycle progression, including the disturbing G1/S process and manifesting G1 cyclin inhibition. Some experiments showed that G1 inhibition was related to the survival state of p53 gene [29-31]. Upon cell exposure to radiation during DNA replication, it would extend the length of or lead to a block in S phase during DNA replication. Furthermore, ataxia telangiectasia mutated (ATM) and DNAdependent protein kinase catalytic subunit (DNA-PKcs) are activated by DNA DSBs, followed by phosphorylation of checkpoint kinase 2 (CHK2) and lead to a block in G2/M phase [32-34]. Cell death events caused by radiation include apoptosis, necrosis, autophagy, mitotic catastrophe, and ferroptosis are related to the sensitivity of different cell types to radiation. Although the common mechanism may be related to damage of nuclear DNA, the specific mechanism involved in cell death still needs further research [35-37].

\section{Conventional treatment for RISI}

Treatment details containing pros and cons of conventional methods for RISI are summarized in Table 1.

\section{Systemic therapy}

Systematic treatment is mainly based on different stages of RISI development, including antibiotics, waterelectrolyte balance, and nutritional support. Experience has shown that infusion of fresh-frozen plasma (FFP), proteinase inhibitors, free-radical scavenger, and drugs of increasing the immunity could alleviate symptoms of RISI patients [38, 39].

\section{Local treatment \\ Topical corticosteroids}

Corticosteroids are widely used to treat dermatitis induced by acute radiation [40]. Shukla et al. reported that the use of corticosteroids could prevent radiationinduced skin toxicity effectively and the incidence of wet desquamation was $13 \%$ in the corticosteroid group than $37 \%$ in control group [42]. Another clinical trial with 120 breast cancer patients enrolled showed that (mometasone furoate) MFF group significantly reduced radiation dermatitis and improved health-related quality of life [41].

\section{Creams and ointments}

Some non-steroidal anti-inflammatory creams and ointments have been applied to attempt to relieve the symptoms of RISI. It has been shown that topical application of triethylamine has a significant advantage in the prevention of radiation dermatitis by early recruitment of macrophages and stimulation of granulation tissue in comparison with the control group [43, 44].

\section{Hydrogel dressings}

Hydrogel is a form of highly cross-linked polymer that is polymerized by hydrophilic and hydrophobic groups and exhibits an outstanding characteristic of biocompatibility [45]. Censabella et al. indicated that patients with breast cancer received hydrogel dressings during radiotherapy period and significantly reduced the incidence of radiation-induced moist desquamation in comparison with the D-panthenol group [46]. 
Table 1 Summary of the pros and cons of conventional treatments for RISI

\begin{tabular}{|c|c|c|c|c|}
\hline $\begin{array}{l}\text { Conventional } \\
\text { treatments }\end{array}$ & Options & Pros & Cons & Reference \\
\hline \multirow[t]{3}{*}{ Systemic therapy } & Antibiotics & Control and eliminate bacterial infection & $\begin{array}{l}\text { Potential risk of antibiotic resistance } \\
\text { occurrence }\end{array}$ & [38-40] \\
\hline & $\begin{array}{l}\text { Water-electrolyte } \\
\text { balance }\end{array}$ & Supplement of loss of water-electrolyte by wounds & $\begin{array}{l}\text { Cardiopulmonary load by excessive } \\
\text { rehydration }\end{array}$ & {$[39,41]$} \\
\hline & $\begin{array}{l}\text { Nutritional } \\
\text { support }\end{array}$ & $\begin{array}{l}\text { Reduce autologous protein degradation and } \\
\text { enhance immunity }\end{array}$ & Burden to kidney and liver & {$[40,42]$} \\
\hline \multirow[t]{6}{*}{ Local treatment } & $\begin{array}{l}\text { Topical } \\
\text { corticosteroids }\end{array}$ & $\begin{array}{l}\text { Anti-inflammation, immunosuppression and anti- } \\
\text { proliferation }\end{array}$ & $\begin{array}{l}\text { Decrease histamine and deplete mast } \\
\text { cells on skin }\end{array}$ & {$[41,43]$} \\
\hline & $\begin{array}{l}\text { Creams and } \\
\text { ointments }\end{array}$ & $\begin{array}{l}\text { Anti-inflammatory and promote macrophages } \\
\text { recruitment }\end{array}$ & $\begin{array}{l}\text { Less effective in managing patient- } \\
\text { reported symptoms }\end{array}$ & {$[44,45]$} \\
\hline & $\begin{array}{l}\text { Hydrogel } \\
\text { dressings }\end{array}$ & Induce healing time, reduce pain and infection & $\begin{array}{l}\text { Less frequent occurrence of severe skin } \\
\text { reactions }\end{array}$ & {$[46,47]$} \\
\hline & $\begin{array}{l}\text { Hyperbaric } \\
\text { oxygen therapy }\end{array}$ & $\begin{array}{l}\text { Increase the oxygen supply, inhibit inflammatory } \\
\text { reaction, and reduce exudation }\end{array}$ & $\begin{array}{l}\text { Arterial insufficiency, refractory } \\
\text { osteomyelitis and bone necrosis }\end{array}$ & {$[48,49]$} \\
\hline & $\begin{array}{l}\text { Superoxide } \\
\text { dismutase }\end{array}$ & Antioxidant enzymes for scavenging free radicals & Not mentioned & {$[50,51]$} \\
\hline & $\begin{array}{l}\text { Low-intensity } \\
\text { laser }\end{array}$ & Reduction of edema and analgesia induction & Not mentioned & {$[50,52]$} \\
\hline
\end{tabular}

\section{Hyperbaric oxygen therapy (HBOT)}

Hyperbaric oxygen therapy (HBOT) could be applied to form a hyperoxia environment in wound surface, keep the wound skin dry, and improve local microenvironment. The use of HBOT directly destroys the living environment of anaerobic bacteria, reduces the chance of bacterial infection, and accelerates the regression of redness and swelling $[47,48]$.

\section{Superoxide dismutase $(S O D)$}

SOD is a kind of antioxidant enzymes for scavenging free radicals in tissues by scavenging superoxide anion to reduce the adverse reactions [49]. Campan et al. reported that skin fibrosis induced by RT in breast cancer patients could be alleviated effectively with topical use of SOD [50].

\section{Low-intensity laser}

Main mechanisms of low-intensity laser for treating radiation dermatitis mainly are related to the expansion in local capillary, increase in vascular permeability, promotion of blood circulation, and proliferation of wound fibroblasts [51, 52].

\section{MSCs for applications in regenerative medicine}

MSCs are multipotent stem cells that can differentiate into a variety of cell types to maintain tissue integrity and intracellular homeostasis [53]. On-going clinical applications involved adipose-derived mesenchymal stem cells (ADMS $\mathrm{Cs}$ ), stromal vascular fractions (SVFs), and platelet-rich plasma (PRP) have raised in regenerative fields enrolling wound healing, scar management, breast augmentation, and soft tissue defects reconstruction [54, 55]. MSC actions through anti-inflammatory and immune-modulatory capabilities by secreting large number of anti-inflammatory cytokines, cell growth factors, antibacterial peptides, and proteins such as IL-17, indoleamine 2,3-dioxygenase (IDO), and other functional molecules $[56,57]$. The application of MSCs to patients after the SARS-CoV-2 infection could alleviate the over-activation of the immune system, improve the lung microenvironment, and reduce the risk of cytokine storm syndrome (CSS) and acute respiratory distress syndrome (ARDS) of the body [58-60]. Animal experiments and clinical applications using MSCs in the treatment of RISI were summarized in Tables 2 and 3.

\section{Adipose-derived mesenchymal stem cells (ADMSCs)}

ADMSC is one of the sources of stem cells which could secrete a variety of cytokines with multiple differentiation potential and immune exemption features. ADMS Cs are extracted from adipose tissue and have biological characteristics of convenient obtain access [66-68]. Pietro et al. identified the phenotype of MSCs and elaborated that transcription factors (including OCT4, SOX2, NANOG, NEUROD1, PAX6, and SOX3) were involved in self-renewal capacity and multi-lineage differentiation potential. They verified the safety and efficacy of human ADMSCs localize in SVFs in breast reconstruction and assessed the volumetric persistence of breast augmentation by fat graft enhanced with ADMSCs in a 5-year follow-up retrospective case series [8, 69-73]. Besides, classic nanofat methods were innovatively modified by Pietro et al. and presented better outcomes of SVFs for the treatment of scars [62, 74-76]. They also proposed the maintenance and survival of SVF-enhanced autologous fat grafts were promoted by mixing with PRP and 
Table 2 Summary of MSC source, injury type, and main findings from the treatment of RISI using MSCs in preclinical studies

\begin{tabular}{|c|c|c|c|c|c|}
\hline Publication & Animal model & MSC source & Injury type & Main findings & Reference \\
\hline $\begin{array}{l}\text { Rong et al. } \\
2019\end{array}$ & $\begin{array}{l}\text { Sprague-Dawley } \\
\text { rat }\end{array}$ & $\begin{array}{l}\text { Human fetal skin-derived } \\
\text { stem cell }\end{array}$ & $\begin{array}{l}\text { Radiation-induced } \\
\text { skin injury }\end{array}$ & Enhanced radiation dermatitis angiogenesis & [1] \\
\hline $\begin{array}{l}\text { Kakabadze et al. } \\
2019\end{array}$ & Lewis inbred rats & Rat bone marrow & $\begin{array}{l}\text { Nonhealing } \\
\text { wounds of } \\
\text { radiation }\end{array}$ & $\begin{array}{l}\text { Closing the burn wound increased the rate of } \\
\text { healing }\end{array}$ & {$[4]$} \\
\hline $\begin{array}{l}\text { Myung et al. } \\
2019\end{array}$ & $\begin{array}{l}\text { SKH-1 hairless } \\
\text { mice }\end{array}$ & $\begin{array}{l}\text { Umbilical cord blood- } \\
\text { derived }\end{array}$ & $\begin{array}{l}\text { Combined } \\
\text { radiation and } \\
\text { wound injury }\end{array}$ & $\begin{array}{l}\text { UCB-MSCs+PRP improve regeneration efficacy } \\
\text { by enhancing angiogenesis }\end{array}$ & {$[7]$} \\
\hline Wu et al. 2018 & Nude mice & Adipose-derived stem & $\begin{array}{l}\text { Cutaneous punch } \\
\text { wounds with } \\
\text { radiation exposure }\end{array}$ & $\begin{array}{l}\text { Revitalized irradiated tissues and accelerated } \\
\text { wound healing }\end{array}$ & {$[10]$} \\
\hline Sun et al. 2018 & $\begin{array}{l}\text { Sprague-Dawley } \\
\text { rat }\end{array}$ & WJ-MSCS & $\begin{array}{l}\text { Radiation-induced } \\
\text { skin injury }\end{array}$ & $\begin{array}{l}\text { Accelerated wound closure and enhanced the } \\
\text { wound healing quality }\end{array}$ & {$[16]$} \\
\hline Liu et al. 2018 & SD rats & Human umbilical cord & $\begin{array}{l}\text { Irradiation-induced } \\
\text { skin ulcers }\end{array}$ & $\begin{array}{l}\text { Promoted neovascularization and } \\
\text { reepithelization, and improved healing of } \\
\text { irradiation-induced skin ulcers }\end{array}$ & [13] \\
\hline Lee et al. 2017 & $\begin{array}{l}\text { Male C57BL/6 } \\
\text { mice }\end{array}$ & $\begin{array}{l}\text { Human umbilical cord } \\
\text { blood-derived }\end{array}$ & $\begin{array}{l}\text { Combined } \\
\text { radiation wound }\end{array}$ & $\begin{array}{l}\text { Enhanced wound healing and angiogenesis in } \\
\text { the wound site }\end{array}$ & [15] \\
\hline $\begin{array}{l}\text { Riccobono et al. } \\
2016\end{array}$ & Minipigs & $\begin{array}{l}\text { Adipose tissue-derived } \\
\text { stromal/stem cells }\end{array}$ & $\begin{array}{l}\text { Cutaneous } \\
\text { radiation } \\
\text { syndrome }\end{array}$ & $\begin{array}{l}\text { Have an effect on both muscle inflammation } \\
\text { and regeneration }\end{array}$ & [20] \\
\hline Jin et al. 2016 & $\begin{array}{l}\text { Sprague-Dawley } \\
\text { rat }\end{array}$ & Rat MSCs+PDGF & $\begin{array}{l}\text { Radiation-induced } \\
\text { skin ulceration }\end{array}$ & Radiation-induced skin ulceration & [22] \\
\hline $\begin{array}{l}\text { Rodriguez- } \\
\text { Menocal et al. } \\
2015\end{array}$ & C57BL/6 mice & $\begin{array}{l}\text { Whole bone marrow, } \\
\text { whole bone marrow } \\
\text { cultured cells, MSCs }\end{array}$ & $\begin{array}{l}\text { Radiation-induced } \\
\text { delayed wound }\end{array}$ & $\begin{array}{l}\text { Mixed bone marrow cell preparations may be } \\
\text { superior to a more purified stem cell } \\
\text { formulation in stimulating wound healing }\end{array}$ & [23] \\
\hline $\begin{array}{l}\text { Horton et al. } \\
2013\end{array}$ & $\mathrm{C} 3 \mathrm{H} / \mathrm{HeN}$ mice & $\begin{array}{l}\text { Syngeneic or allogeneic } \\
\text { BMSC }\end{array}$ & IR-induced fibrosis & $\begin{array}{l}\text { Alter the progression of radiation-induced fi } \\
\text { brosis by altering macrophage phenotype and } \\
\text { suppressing local inflammation }\end{array}$ & [61] \\
\hline $\begin{array}{l}\text { Huang et al. } \\
2013\end{array}$ & $\begin{array}{l}\text { Sprague-Dawley } \\
\text { rat }\end{array}$ & $\begin{array}{l}\text { Adipose-derived stem } \\
\text { cells }\end{array}$ & $\begin{array}{l}\text { Acute radiation } \\
\text { ulcers }\end{array}$ & $\begin{array}{l}\text { Contributed to vascularization by acting as } \\
\text { angiogenesis-promoting cells }\end{array}$ & [26] \\
\hline $\begin{array}{l}\text { Forcheron et al. } \\
2012\end{array}$ & Minipigs & $\begin{array}{l}\text { Autologous adipose } \\
\text { MSCs }\end{array}$ & $\begin{array}{l}\text { Cutaneous } \\
\text { radiation } \\
\text { syndrome }\end{array}$ & $\begin{array}{l}\text { Attracted numerous immune cells and } \\
\text { accumulated at the dermis/subcutis barrier }\end{array}$ & [27] \\
\hline Agay et al. 2010 & Minipig & $\begin{array}{l}\text { Autologous bone } \\
\text { marrow }\end{array}$ & $\begin{array}{l}\text { Cutaneous } \\
\text { radiation } \\
\text { syndrome }\end{array}$ & $\begin{array}{l}\text { Led to local accumulation of lymphocytes and } \\
\text { improved vascularization }\end{array}$ & [30] \\
\hline $\begin{array}{l}\text { Riccobono et al. } \\
2012\end{array}$ & Minipig & $\begin{array}{l}\text { Adipocyte-derived stem } \\
\text { cells }\end{array}$ & $\begin{array}{l}\text { Cutaneous } \\
\text { radiation } \\
\text { syndrome }\end{array}$ & Improved wound healing & [32] \\
\hline $\begin{array}{l}\text { Horton et al. } \\
2013\end{array}$ & $\begin{array}{l}\text { Female } \mathrm{C} 3 \mathrm{H} / \mathrm{HEN} \\
\text { mice }\end{array}$ & Mouse bone marrow & $\begin{array}{l}\text { Cutaneous } \\
\text { radiation } \\
\text { syndrome }\end{array}$ & Reduced inflammation and fibrosis & [33] \\
\hline $\begin{array}{l}\text { Zheng et al. } \\
2015\end{array}$ & $\begin{array}{l}\text { Sprague-Dawley } \\
\text { rat }\end{array}$ & Rat bone marrow & $\begin{array}{l}\text { Radiation-induced } \\
\text { skin injury }\end{array}$ & $\begin{array}{l}\text { Reduced inflammation, decreased expression } \\
\text { of PGE2 and TGF- } \beta 1\end{array}$ & {$[38]$} \\
\hline Xia et al. 2014 & $\begin{array}{l}\text { Sprague-Dawley } \\
\text { rat }\end{array}$ & $\begin{array}{l}\text { Rat bone marrow MSCs } \\
\text { expressing human VEGF } \\
\text { and beta-defensin-3 }\end{array}$ & $\begin{array}{l}\text { Radiation and } \\
\text { excisional injury }\end{array}$ & $\begin{array}{l}\text { Improved skin appendage regeneration and } \\
\text { collagen deposition; shortened wound healing } \\
\text { duration }\end{array}$ & {$[45]$} \\
\hline Xie et al. 2013 & $\begin{array}{l}\text { C3Hf/Kam female } \\
\text { and } \mathrm{C} 57 \mathrm{BI} / 6 \text { male } \\
\text { gnotobiotic mice }\end{array}$ & Murine bone & $\begin{array}{l}\text { Radiation-induced } \\
\text { wound }\end{array}$ & $\begin{array}{l}\text { Haptized collagen strips to reduce radiation } \\
\text { wound-healing deficits }\end{array}$ & {$[54]$} \\
\hline $\begin{array}{l}\text { Kotenko et al. } \\
2012\end{array}$ & Male Wistar rats & Rats bone marrow & $\begin{array}{l}\text { Radiation skin } \\
\text { damage }\end{array}$ & $\begin{array}{l}\text { Normalize intercellular interaction and } \\
\text { influence the processes of proliferation and } \\
\text { differentiation of skin cells }\end{array}$ & [8] \\
\hline Yan et al. 2011 & Minipigs & $\begin{array}{l}\text { MSCs expressing hPDGF } \\
\text { loaded onto acellular } \\
\text { amniotic membrane }\end{array}$ & $\begin{array}{l}\text { Radiation and } \\
\text { excisional injury }\end{array}$ & $\begin{array}{l}\text { Improved granulation, re-epithelialization and } \\
\text { angiogenesis }\end{array}$ & {$[62]$} \\
\hline
\end{tabular}


Table 2 Summary of MSC source, injury type, and main findings from the treatment of RISI using MSCs in preclinical studies (Continued)

\begin{tabular}{|c|c|c|c|c|c|}
\hline Publication & Animal model & MSC source & Injury type & Main findings & Reference \\
\hline $\begin{array}{l}\text { Ebrahimian } \\
\text { et al. } 2009\end{array}$ & $\begin{array}{l}\text { C57BI/6 male } \\
\text { mice }\end{array}$ & Homogenous ADSCs & $\begin{array}{l}\text { Skin punched } \\
\text { wounds and then } \\
\text { irradiated }\end{array}$ & $\begin{array}{l}\text { Promoted dermal wound healing and enhanced } \\
\text { wound closure }\end{array}$ & [63] \\
\hline Hao et al. 2008 & $\begin{array}{l}\text { Sprague-Dawley } \\
\text { rat }\end{array}$ & $\begin{array}{l}\text { Rat bone marrow MSCs } \\
\text { expressing human PDGF } \\
\text { and beta-defensin-2 }\end{array}$ & $\begin{array}{l}\text { Radiation and } \\
\text { excisional injury }\end{array}$ & $\begin{array}{l}\text { Improved granulation tissue formation } \\
\text { and reduced bacterial load }\end{array}$ & [64] \\
\hline $\begin{array}{l}\text { Francois et al. } \\
2007 ; \\
\text { Mouiseddine } \\
\text { et al. } 2007\end{array}$ & NOD/SCID mice & Human bone marrow & $\begin{array}{l}\text { Radiation } \\
\text { dermatitis }\end{array}$ & Improved wound healing & [65] \\
\hline
\end{tabular}

showed better outcomes of scars on the face compared with traditional surgical methods [63-65, 77]. Maria et al. combined PRP/insulin by improving chondrogenic and osteogenic differentiation of ADMSCs in a 3D collagen scaffold for treating osteochondral defects [78, 79].

Results of current applications with MSCs especially with ADMSCs indicated ADMSCs being new, alternative while bright approaches for treating those who suffer from the COVID-19 pandemic caused by coronavirus 2 (SARS-CoV-2) because of its easy access from autologous abdominal subcutaneous fat with low immunogenicity and little ethical disputes [80-82].

Bone marrow-derived mesenchymal stem cells (BMMSCs) BMMSCs own the ability to differentiate into osteoblasts, chondroblasts, tendon cells, endothelial cells, glial cells, and hepatocyte. In view of the unique clinical and biological characteristics such as secretion of various hematopoietic growth factors, reconstruction of hematopoietic microenvironment, low immunogenicity together with vulnerable to transfection, and expression of foreign gene products, BMMSCs could partly make up for the deficiency of traditional treatment [83, 84]. BMMSCs still maintain its multi-directional differentiation potential and induce amplification in a destroyed tissue environment to participate in tissue repair or regeneration process $[70,85]$.

\section{Umbilical cord mesenchymal stem cells (UCMSCs)}

In recent years, UCMSCs have attracted more attention because of the stronger ability of proliferation and differentiation compared with BMMSCs. Apart from antiinflammatory properties, UCMSCs play numerous roles in promoting systemic and local tissue repair, enhancing the ability of autophagy and self-repair together with increasing oxidative stress resistance in order to promote angiogenesis [86, 87]. Fang et al. studied that UCMSCderived exosomes could reduce the myogenesis fibroblast accumulation and scar formation in a mouse wound defect model [88]. Wang et al. reported that

Table 3 Summary of MSC source, injury type, and main findings from the treatment of RISI using MSCs in clinical applications

\begin{tabular}{|c|c|c|c|c|c|}
\hline Publication & MSC source & Combined treatment & Injury type & Main findings & Reference \\
\hline $\begin{array}{l}\text { Portas et al. } \\
2016\end{array}$ & $\begin{array}{l}\text { Allogenic } \\
\text { cadaveric bone } \\
\text { marrow }\end{array}$ & $\begin{array}{l}\text { Surgical methods, hyperbaric } \\
\text { oxygen treatment }\end{array}$ & $\begin{array}{l}\text { Radiation-induced } \\
\text { chronic skin lesions }\end{array}$ & $\begin{array}{l}\text { Ulcer dimensions were reduced and } \\
\text { remission of signs and symptoms }\end{array}$ & [2] \\
\hline $\begin{array}{l}\text { Guo et al. } \\
2014\end{array}$ & $\begin{array}{l}\text { Allogeneic bone } \\
\text { marrow }\end{array}$ & $\begin{array}{l}\text { HLA-mismatched peripheral } \\
\text { blood stem cell } \\
\text { transplantation }\end{array}$ & $\begin{array}{l}\text { Radioactive skin } \\
\text { ulceration }\end{array}$ & $\begin{array}{l}\text { Suggesting a potential benefit of MSCs in } \\
\text { radiation treatments }\end{array}$ & {$[5]$} \\
\hline $\begin{array}{l}\text { Kotenko } \\
\text { et al. } 2012\end{array}$ & $\begin{array}{l}\text { Human bone } \\
\text { marrow }\end{array}$ & $\begin{array}{l}\text { Surgery and traditional } \\
\text { conservative therapy }\end{array}$ & $\begin{array}{l}\text { Severe local radiation } \\
\text { ulcers }\end{array}$ & $\begin{array}{l}\text { Rapid growth of granulation tissue and } \\
\text { marginal epithelization and reduction in the } \\
\text { ulcer }\end{array}$ & {$[8]$} \\
\hline $\begin{array}{l}\text { Bey et al. } \\
2010\end{array}$ & $\begin{array}{l}\text { Autologous } \\
\text { bone marrow }\end{array}$ & Skin autograft & $\begin{array}{l}\text { Severe radiation burn } \\
\text { and radiation } \\
\text { dermatitis }\end{array}$ & Modulating radiation inflammatory processes & {$[12]$} \\
\hline $\begin{array}{l}\text { Benderitter } \\
\text { et al. } 2010\end{array}$ & $\begin{array}{l}\text { Autologous } \\
\text { bone marrow }\end{array}$ & Plastic surgery or skin graft & $\begin{array}{l}\text { Severe radiological } \\
\text { burn }\end{array}$ & $\begin{array}{l}\text { Being driven by the quality and the rapidity } \\
\text { of the wound healing }\end{array}$ & {$[14]$} \\
\hline $\begin{array}{l}\text { Akita et al. } \\
2010\end{array}$ & $\begin{array}{l}\text { Autologous } \\
\text { adipose tissue }\end{array}$ & $\begin{array}{l}\text { Temporal artificial dermis } \\
\text { impregnated+BFGF }\end{array}$ & $\begin{array}{l}\text { Chronic radiation } \\
\text { injuries }\end{array}$ & $\begin{array}{l}\text { Wound was healed and no sign of recurrence } \\
\text { appeared }\end{array}$ & [17] \\
\hline $\begin{array}{l}\text { Lataillade } \\
\text { et al. } 2007\end{array}$ & $\begin{array}{l}\text { Autologous } \\
\text { bone marrow }\end{array}$ & Surgery & Radiation burn & $\begin{array}{l}\text { Open new prospects in radiotherapy } \\
\text { complications }\end{array}$ & {$[19]$} \\
\hline
\end{tabular}


human UCMSCs present positive treatment effects on acute radiation enteritis in rats [89].

\section{Discussions}

Various reasons include RT, occupational exposure, nuclear leakage accident, or/and nuclear war would lead to RISI that characterized by potential progressiveness and difficult to heal [90, 91]. Stewart et al. indicated that radiation-induced changes of signal molecule levels and formation of oxygen free radicals would cause DNA single-strand breaks, resulting in incomplete repair, premature senility, and accelerated differentiation [92].

The mechanisms of MSCs involved in wound progression are mainly through direct differentiation, immunomodulation, paracrine actions, and other related mechanisms such as recruitment of endogenous stem/ progenitor cells, antibacterial and antioxidant effects with the intent of improving the wound microenvironment, shortening the inflammatory phase, and accelerating the proliferation phase to regulate matrix deposition and collagen remodeling, so as to arrive the accelerated healing and less scar formation [41, 54, 93] (Fig. 3). The inflammatory cytokines (e.g., anti-inflammatory cytokines like interleukin-10 (IL-10) and interleukin-4 (IL-4) and inflammatory factors such as tumor necrosis factor $\alpha($ TNF- $\alpha)$ and interferon $\beta$ (IFN- $\beta$ )) and immune cells of wounds could activate MSCs that associated with proliferation and secretion of different immune cell subsets. Besides, MSCs promote the transformation of macrophages from M1-type to M2-type to accelerate the process of wound repair [94-96].

MSCs can be differentiated into keratinocytes, endothelial cells, sweat gland cells, or dermal papilla cells to participate in wound repair after direct induction in vitro. ADMSCs were obtained from the adipose tissues and are characterized by abundant sources and easy access compared to other sources of MSCs such as BMMSCs and UCMSCs. Altman et al. indicated that ADMSCs with fluorescent protein marked to dermal scaffolds could detect the expression of heat shock protein 47 (HSP-47) through fibroblast differentiation [97]. Ebrahimian et al. detected the expression of keratin 5 (K5) and keratin 14 (K14) which are signs of keratinocytes in epidermis after injection of ADMSCs into the back muscles of mice and indicated the differentiation potential of ADMSCs to epidermal keratinocytes [63]. Because of their lower immunogenicity, with no or low expression of major histocompatibility complex (MHC), host immune reaction is rarely caused after transplantation of ADMSCs [60, 91].

In recent years, BMMSCs have been one of the research hotspots for regenerative medicine with the following biological characteristics: (1) BMMSCs were able to grow adhering to the wall of the culture dishes; (2)

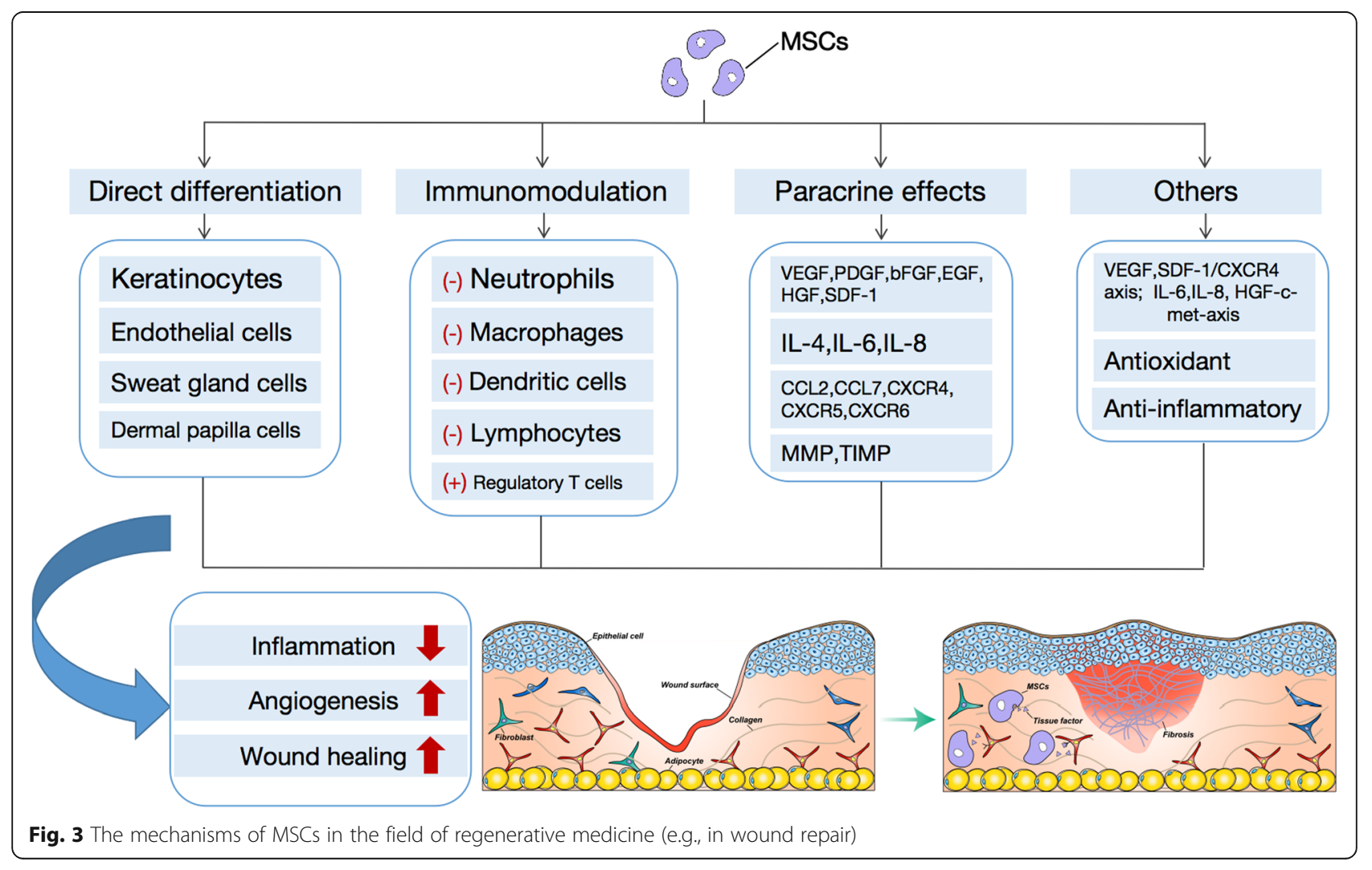


the cell surface phenotype were CD3, CD4, CD8, CD14, CD19, CD34, CD45, and HLA-DR negative and CD29, CD44, CD71, CD73, CD90, CD105, and CD124 positive; (3) medium levels of positive MHC I expression and no expression of MHC II; (4) no expression of costimulatory molecules like B7-1, CD40, and CD86 [60, 92-94, $98,99]$. Silva et al. reported that BMMSCs could differentiate into vascular endothelial cells in vivo microenvironment and result in re-epithelialization of the wounded tissues [100]. Recent research has shown that MSCs participate in wound repair through paracrine growth factors, cytokines, and chemokines which have been described before. Some researchers reported that BMMSCs could be induced in radioactive environments that lead to further amplification to participate in tissue repair and regeneration process, resulting in achieving the purpose of MSCs transplantation in the treatment of radiation injury [101-103]. HGF and PGE2 that secreted by MSCs could, on the one hand, regulate the balance of TGF- $\beta 1$ and TGF- $\beta 2$ on the wound surface and, on the other hand, inhibit the EMT process to inhibit the formation of myofibroblasts and lead to less scar outcomes.

Though BMMSCs have been widely studied in recent years, obtaining BMMSCs would bring risks to patients because of the invasive operation which might restrict the application of BMMSCs [104, 105]. Umbilical cord blood contains a large number of MSCs with multilineage differentiation potential and homing properties. UCMSCs could be derived from a wide range of sources with easier access and lower immunogenicity compared with other sources of MSCs [106, 107]. Human UCMSCs promote neovascularization and reepithelization to enhance the healing of radiation-induced skin ulcer might be activated by PI3K/Akt signaling pathway [108]. In addition, the result in the study indicated the regulatory effect UCMSCs to Flt-3L and TGF- $\beta 1$. What is more, VEGF/SDF-1-CXCR4, inflammatory cytokines (e.g., IL-6 and IL-8), and growth factor receptor axis (e.g., HGF-c-met and PDGF axis) are involved in the recruitment of endogenous stem/progenitor cells of MSCs to promote tissue repair $[83,109-111]$.

\section{Conclusion}

Many studies have confirmed the effects of MSCs on tissue repair as an acellular therapy in recent years. This review focused on the latest application of MSCs from various sources as a promising agent for RISI both in animal models and clinical trials and discussed related mechanism. The specific mechanism of MSCs on tissue repair and regenerative medicine need to be further studied in the future.

\section{Abbreviations}

RISI: Radiation-induced skin injury; RT: Radiotherapy; MSCs: Mesenchymal stem cells; ROS: Reactive oxygen species; NO: Nitric oxide; RNS: Reactive nitrogen species; HMGB1: High mobility group box 1; ATM: Ataxia telangiectasia mutated; DNA-PKcs: DNA-dependent protein kinase catalytic subunit; FFP: Fresh-frozen plasma; HBOT: Hyperbaric oxygen therapy; CHK2: Checkpoint kinase 2; SVFs: Stromal vascular fractions; PRP: Platelet-rich plasma; SOD: Superoxide dismutase; VEGF: Vascular endothelial growth factor; IDO: Indoleamine 2,3-dioxygenase; PDGF: Platelet-derived growth factor; CSS: Cytokine storm syndrome; ARDS: Acute respiratory distress syndrome; ADMSCs: Adipose-derived mesenchymal stem cells; BMMSCs: Bone marrow-derived mesenchymal stem cells; UCMSCs: Umbilical cord mesenchymal stem cells; SARS-CoV-2: Coronavirus 2; IL-10: Interleukin10; IL-4: Interleukin-4; TNF-a: Tumor necrosis factor a; IFN- $\beta$ : Interferon $\beta$; HSP-47: Heat shock protein 47; K5: Keratin 5; K14: K14 keratin; MHC: Major histocompatibility complex

\section{Acknowledgements}

We thank Haoruo Zhang and Caixiang Chen for their help to the manuscript. This work was financed by National Natural Science Foundation of China (grant No. 81971855, 81671930), Joint funding Project of Science and Technology Innovation in Fujian Province (grant No. 2017Y9101), Special Financial Funds of Fujian Province (grant No. 2018B054), and Industrial Technology Joint Innovation Project of Fujian Provincial Development and Reform Commission (grant No. 2011601).

\section{Authors' contributions}

$X C$ designed the manuscript. ZF wrote the text. PC, ST, and AC revised the format of the figures. CZ, GP, and ML revised the manuscript. XC approved the final submission. All authors discussed the results and reviewed the manuscript. The authors read and approved the final manuscript.

\section{Funding}

This work was financed by National Natural Science Foundation of China (grant No. 81971855, 81671930), Joint funding Project of Science and Technology Innovation in Fujian Province (grant No. 2017Y9101), Special Financial Funds of Fujian Province (grant No. 2018B054), and Industrial Technology Joint Innovation Project of Fujian Provincial Development and Reform Commission (grant No. 2011601).

\section{Availability of data and materials}

Not applicable.

\section{Declarations}

Ethics approval and consent to participate Not applicable.

\section{Consent for publication}

Not applicable.

\section{Competing interests}

The authors declare no competing interests.

Received: 20 January 2021 Accepted: 1 March 2021

Published online: 12 March 2021

References

1. Rong X, Li J, Yang Y, Shi L, Jiang T. Human fetal skin-derived stem cell secretome enhances radiation-induced skin injury therapeutic effects by promoting angiogenesis. Stem Cell Res Ther. 2019;10:383.

2. Portas M, Mansilla E, Drago H, Dubner D, Radl A, Coppola A, Di Giorgio M. Use of human cadaveric mesenchymal stem cells for cell therapy of a chronic radiation-induced skin lesion: a case report. Radiat Prot Dosim. 2016; 171(1):99-106.

3. Carter S, Zahs A, Palmer J, Wang L, Ramirez L, Gamelli R, Kovacs E. Intestinal barrier disruption as a cause of mortality in combined radiation and burn injury. Shock. 2013;40(4):281-9.

4. Kakabadze Z, Chakhunashvili D, Gogilashvili K, Ediberidze K, Chakhunashvili K, Kalandarishvili K, Karalashvili L. Bone marrow stem cell and decellularized human amniotic membrane for the treatment of nonhealing wound after radiation therapy. Exp Clin Transplant. 2019;17(null):92-8.

5. Guo M, Dong Z, Jianhui Q, Yu C, Qiyun S, Hu K, Guangxian L, Li W, Bo Y, Qiuhong $M$, et al. Severe acute radiation syndrome: treatment of a lethally 
60Co-source irradiated accident victim in China with HLA-mismatched peripheral blood stem cell transplantation and mesenchymal stem cells. J Radiat Res. 2014;55(2):205-9.

6. Mendoza A, Neely C, Charles A, Kartchner L, Brickey W, Khoury A, Sempowski G, Ting J, Cairns B, Maile R. Radiation combined with thermal injury induces immature myeloid cells. Shock. 2012;38(5):532-42.

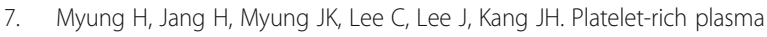
improves the therapeutic efficacy of mesenchymal stem cells by enhancing their secretion of angiogenic factors in a combined radiation and wound injury model. Exp Dermatol. 2020;29:158-167.

8. Kotenko K, Moroz B, Nadezhina N, Galstyan I, Eremin I, Deshevoy J, Lebedev V, Slobodina T, Grinakovskaya D, Zhgutov Y, et al. Successful treatment of localised radiation lesions in rats and humans by mesenchymal stem cell transplantation. Radiat Prot Dosim. 2012;151(4):661-5.

9. Ablordeppey E, Drewry A, Theodoro D, Tian L, Fuller BM, Griffey R. Current practices in central venous catheter position confirmation by point of care ultrasound: a survey of early adopters. Shock. 2019;51(5):613-8.

10. Wu S, Shirado T, Mashiko T, Feng J, Asahi R, Kanayama K, Mori M, Chi D, Sunaga A, Sarukawa S. Therapeutic effects of human adipose-derived products on impaired wound healing in irradiated tissue. Plast Reconstr Surg. 2018;142(2):383-91.

11. Kalns J, Ryan K, Mason P, Bruno J, Gooden R, Kiel J. Oxidative stress precedes circulatory failure induced by 35-ghz microwave heating. Shock. 2000;13(1):52-9.

12. Eric B, Marie P, Patrick D, Marc B, Michel B, François T, Pierre B, Isabelle E, Laetitia B, Muriel G. Emerging therapy for improving wound repair of severe radiation burns using local bone marrow-derived stem cell administrations. Wound Repair Regen. 2010;18(1):50-8.

13. Liu Z, Yu D, Xu J, Li X, Wang X, He Z, Zhao T. Human umbilical cord mesenchymal stem cells improve irradiation-induced skin ulcers healing of rat models. Biomed Pharmacother. 2018;101:729.

14. Benderitter M, Gourmelon P, Bey E, Chapel A, Clairand I, Prat M, Lataillade J. New emerging concepts in the medical management of local radiation injury. Health Phys. 2010;98:851-7.

15. Lee C, Shim S, Jang H, Myung H, Lee J, Bae C, Myung J, Kim M, Lee S, Jang W. Human umbilical cord blood-derived mesenchymal stromal cells and small intestinal submucosa hydrogel composite promotes combined radiation-wound healing of mice. Cytotherapy. 2017;19(9):1048-59.

16. Sun J, Zhang $Y$, Song $X$, Zhu J, Zhu Q. The healing effects of conditioned medium derived from mesenchymal stem cells on radiation-induced skin wounds in rats. Cell Transplant. 2018;28:105-15.

17. Akita S, Akino K, Hirano A, Ohtsuru A, Yamashita S. Noncultured autologous adipose-derived stem cells therapy for chronic radiation injury. Stem Cells Int. 2010;2010:532704

18. Goessler U, Bugert P, Kassner S, Stern-Straeter J, Bran G, Sadick H, Hörmann $K$, Riedel Frank: In vitro analysis of radiation-induced dermal wounds. Otolaryngol Head Neck Surg, 2010,142(6), 845-850.

19. Lataillade J, Doucet C, Bey E, Carsin H, Huet C, Clairand I, Bottollier J, Chapel A, Ernou I, Gourven M, et al. New approach to radiation burn treatment by dosimetry-guided surgery combined with autologous mesenchymal stem cell therapy. Regen Med. 2007;2(5):785-94

20. Riccobono D, Agay D, François S, Scherthan H, Drouet M, Forcheron F Contribution of intramuscular autologous adipose tissue-derived stem cell injections to treat cutaneous radiation syndrome: preliminary results. Health Phys. 2016;111(2):117-26.

21. Biju P, Garg S, Wang W, Choudhry M, Kovacs E, Fink L, Hauer J. Procalcitonin as a predictive biomarker for total body irradiation-induced bacterial load and lethality in mice. Shock. 2012;38(2):170-6.

22. Jin I, Kim J, Wu H, Hwang S. Effect of mesenchymal stem cells and plateletderived growth factor on the healing of radiation induced ulcer in rats. Tissue Eng Regen Med. 2016;13(1):78-90.

23. Rodriguez M, Shareef $S$, Salgado M, Shabbir A, Van B. Role of whole bone marrow, whole bone marrow cultured cells, and mesenchymal stem cells in chronic wound healing. Stem Cell Res Ther. 2015;6(1):24.

24. Frei $M$, Ryan $K$, Berger $R$, Jauchem J. Sustained 35-GHz radiofrequency irradiation induces circulatory failure. Shock. 1995;4(4):289-93.

25. Simon P, Lorton F, Guiziou N, Levieux K, Vrignaud B, Masson D, Dupas B, Gras L. Serum S100 $\beta$ neuroprotein reduces use of cranial computed tomography in children after minor head trauma. Shock. 2015;44(5):410-6.

26. Huang S, Huang C, Shyu J, Lee H, Chen S, Chan J, Huang S. Promotion of wound healing using adipose-derived stem cells in radiation ulcer of a rat model. J Biomed Sci. 2013;20(1):51.
27. Ryan K, Frei M, Berger R, Jauchem J. Does nitric oxide mediate circulatory failure induced by 35-GHz microwave heating? Shock. 1996;6(1):71-6.

28. Forcheron F, Agay D, Scherthan H, Riccobono D, Herodin F, Meineke V, Drouet M. Autologous adipocyte derived stem cells favour healing in a minipig model of cutaneous radiation syndrome. PLoS One. 2012;7:e31694.

29. Ryan K, Frei M, Jauchem J. Circulatory failure induced by $35 \mathrm{GHz}$ microwave heating: effects of chronic nitric oxide synthesis inhibition. Shock. 1997;7(1): 70-6.

30. Diane A, Harry S, Fabien F, Nancy G, Francis H, Viktor M, Michel D. Multipotent mesenchymal stem cell grafting to treat cutaneous radiation syndrome: development of a new minipig model. Exp Hematol. 2010;38(10): 945-56.

31. Tharakan B, Hunter F, Smythe W, Childs E. Alpha-lipoic acid attenuates hemorrhagic shock-induced apoptotic signaling and vascular hyperpermeability. Shock. 2008;30(5):571-7.

32. Diane R, Diane A, Harry S, Fabien F, Mylène V, Bruno B, Viktor M, Michel D. Application of adipocyte-derived stem cells in treatment of cutaneous radiation syndrome. Health Phys. 2012;103(2):120.

33. Jason A, Kathryn E, Eun J, Ayla O, Bradley T, Jeffrey F, Deborah E. Mesenchymal stem cells inhibit cutaneous radiation-induced fibrosis by suppressing chronic inflammation. Stem Cells. 2013;31(10):2231-41.

34. Patel D, Mittal S, Tiwari N, Maurya A, Singh D, Pandey A, Pal A. Plasmodiumsalmonella coinfection induces intense inflammatory response, oxidative stress, and liver damage: a mice model study for therapeutic strategy. Shock. 2018;50(6):741-9.

35. Tânia G, Song Y, Brede D, Xie L, Gutzkow K, Salbu B. Gamma radiation induces dose-dependent oxidative stress and transcriptional alterations in the freshwater crustacean daphnia magna. Sci Total Environ. 2018;620629(JUL.1):206-16.

36. Aura R, Bibiana $V$, Tautgirdas $R$, Sebastian B. The effect of UVB irradiation and oxidative stress on the skin barrier-a new method to evaluate sun protection factor based on electrical impedance spectroscopy. Sensors (Basel). 2019;19(10):2376.

37. Hsu D, Li Y, Chien S, Liu M. Effects of sesame oil on oxidative stress and hepatic injury after cecal ligation and puncture in rats. Shock. 2004;21(5): 466-9.

38. Zheng K, Wu W, Yang S, Huang L, Chen J, Gong C, Fu Z, Zhang L, Tan T. Bone marrow mesenchymal stem cell implantation for the treatment of radioactivityinduced acute skin damage in rats. Mol Med Rep. 2015;12:7065-71.

39. Ahmed N, Radwan N, Aboul E, Salama N. The antioxidant effect of Green Tea Mega EGCG against electromagnetic radiation-induced oxidative stress in the hippocampus and striatum of rats. Electromagn Biol Med. 2017;36(1): 63-73.

40. Singh K, Gautam R, Meena R, Nirala J, Jha S, Rajamani P. Effect of mobile phone radiation on oxidative stress, inflammatory response, and contextual fear memory in wistar rat. Environ Sci Pollut Res Int. 2020;27(16):19340-51.

41. Holmes C, Plichta J, Gamelli R, Radek K. Burn injury alters epidermal cholinergic mediators and increases HMGB1 and Caspase 3 in autologous donor skin and burn margin. Shock. 2017:47(2):175-83.

42. Cejka C, Kossl J, Hermankova B, Holan V, Kubinova S, Zhang J. Therapeutic effect of molecular hydrogen in corneal uvb-induced oxidative stress and corneal photodamage. Sci Rep. 2017;7(1):18017.

43. Oliveirag G, Shimoda K, Enkhbaatar P, Jodoin J, Burke A, Chinkes D. Skin nitric oxide and its metabolites are increased in nonburned skin after thermal injuries. Shock. 2004;22(3):278-82.

44. Breslin J, Wu M, Guo M, Reynoso R, Yuan S. Toll-like receptor 4 contributes to microvascular inflammation and barrier dysfunction in thermal injury. Shock. 2008;29(3):1.

45. Xia Z, Zhang C, Zeng $Y$, Wang $T$, Ai G. Transplantation of BMSCs expressing hVEGF165/hBD3 promotes wound healing in rats with combined radiationwound injury. Int Wound J. 2014;11:293-303.

46. Kruse J, Strootman E, Bart C, Visser A, Leer J, Wondergem J. Radiationinduced changes in gene expression and distribution of atrial natriuretic peptide (ANP) in different anatomical regions of the rat heart. Int J Radiat Biol. 2002;78(4):297-304

47. Yarnold J, Brotons M. Pathogenetic mechanisms in radiation fibrosis. Radiother Oncol. 2010;97(1):149-61.

48. Etulain J. Platelets in wound healing and regenerative medicine. Platelets. 2018;29(6):556-68

49. Miron R, Dard M, Weinreb M. Enamel matrix derivative, inflammation and soft tissue wound healing. J Periodontal Res. 2015;50(5):555-69. 
50. Litvin F, Vasilieva G, Baranov V. Functional features of microcirculation system and its possibilities of oxygen transport in children and youths of Bryansk region in conditions of radioecological pressure. Radiats Biol Radioecol. 2016;56(5):514-22.

51. Wei L, Zhang J, Xiao X, Mai H, Zheng K, Sun W, Ke Z, Lei W, Feng L, Yuan L, et al. Multiple injections of human umbilical cord-derived mesenchymal stromal cells through the tail vein improve microcirculation and the microenvironment in a rat model of radiation myelopathy. J Transl Med. 2014;12(1):246.

52. Michael W, Raphael G, Ewa D, Natalia C, Elena G, Lilia L, William H. Marrowderived stromal cell delivery on fibrin microbeads can correct radiationinduced wound-healing deficits. J Investig Dermatol. 2013;133(2):553-61.

53. Okazaki S, Funasaka Y, Wakamatsu K, Kawana S, Saeki H. Effect of infrared radiation a on photoaged hairless mice harboring eumelanin and pheomelanin in the epidermis. J Dermatol. 2015;42(4):382-90.

54. Hasoun L, Bailey S, Outlaw K, Ayling J. Rearrangement and depletion of folate in human skin by ultraviolet radiation. Br J Dermatol. 2015;173(4): 1087-90.

55. Johnson Jodi L., Koetsier Jennifer L., Sirico Anna., Agidi Ada T., Antonini Dario., Missero C, Green K: The desmosomal protein desmoglein 1 aids recovery of epidermal differentiation after acute UV light exposure. J Invest Dermatol, 2014,134(8), 2154-2162.

56. Auerswald S, Schreml S, Meier R, Soares A, Haubner F. Wound monitoring of $\mathrm{pH}$ and oxygen in patients after radiation therapy. Radiat Oncol. 2019;14(1): 199.

57. Alhasaniah A, Sherratt M, O'Neill C. The impact of ultraviolet radiation on barrier function in human skin: molecular mechanisms and topical therapeutics. Curr Med Chem. 2018;25(40):5503-11.

58. Jörg R, Reichrath S. Hope and challenge: the importance of ultraviolet (UV) radiation for cutaneous vitamin D synthesis and skin cancer. Scand J Clin Lab Invest Suppl. 2012;243:112-9.

59. Hart $P$, Mary N, Byrne S, Lesley E. Exposure to ultraviolet radiation in the modulation of human diseases. Ann Rev Pathol Mech Dis. 2019;14(1):421058260.

60. Christopher I, Kimberly P, Roger E, Nicholas J, Michael K, Raymond S, Steven E. Efficacy of corticosteroids and external beam radiation in the management of moderate to severe thyroid eye disease. J Neuroophthalmol. 2007;27(3):205.

61. Horton J, Hudak K, Chung E, White A, Scroggins B, Burkeen J, Citrin D. Mesenchymal stem cells inhibit cutaneous radiation-induced fibrosis by suppressing chronic inflammation. Stem Cells. 2013;31(10):2231-41.

62. Pietro G, Claudio C, Barbara DA, et al. Impact of the different preparation methods to obtain human adipose-derived stromal vascular fraction cells (AD-SVFs) and human adipose-derived mesenchymal stem cells (AD-MSCs): enzymatic digestion versus mechanical centrifugation. Int J Mol Sci. 2019; 20(21):5471.

63. Cervelli V, Bocchini I, Di Pasquali C, et al. P.R.L. platelet rich lipotransfert: our experience and current state of art in the combined use of fat and PRP. Biomed Res Int. 2013;2013:434191.

64. Giovanna SM, Alessandra B, Pietro G, et al. Combined treatment with platelet-rich plasma and insulin favours chondrogenic and osteogenic differentiation of human adipose-derived stem cells in three-dimensional collagen scaffolds. J Tissue Eng Regen Med. 2017;11:2398-410.

65. Pietro G, Giovanna SM, Alessandra B, et al. Concise review: the use of adipose-derived stromal vascular fraction cells and platelet rich plasma in regenerative plastic surgery. Stem Cells. 2017;35:117-34.

66. Shukla T, Sands B. Novel non-biologic targets for inflammatory bowel disease. Curr Gastroenterol Rep. 2019;21(5):22.

67. Liao Y, Feng G, Dai T, Long F, Tang J, Pu Y, Zheng X, Cao S, Xu S, Du X. Randomized, self-controlled, prospective assessment of the efficacy of mometasone furoate local application in reducing acute radiation dermatitis in patients with head and neck squamous cell carcinomas. Medicine (Baltimore). 2019;98(52):e18230.

68. Abbas H, René-Jean B. Trolamine emulsion for the prevention of radiation dermatitis in patients with squamous cell carcinoma of the head and neck. Support Care Cancer. 2012;20(1):185-90

69. Elliott E. Phase III trial of an emulsion containing trolamine for the prevention of radiation dermatitis in patients with advanced squamous cell carcinoma of the head and neck: results of Radiation Therapy Oncology Group Trial 99-13. J Clin Oncol. 2006;24(13):2092-7.
70. William J, Steve W, Geert W, David H, Raul C, Tony E. Characterization of two classes of pancreatic shock factors: functional differences exhibited by hydrophilic and hydrophobic shock factors. Shock. 2003;20(4):356-62.

71. Censabella S, Claes S, Orlandini M, Braekers R, Bulens P. Efficacy of a hydroactive colloid gel versus historical controls for the prevention of radiotherapy-induced moist desquamation in breast cancer patients. Eur J Oncol Nurs. 2017;29:1-7.

72. Legeza V, Galenko Y, Zinov'ev E, Paramonov B, Kreichman G, Turkovskii I, Gumenyuk E, Karnovich A, Khripunov A. Effects of new wound dressings on healing of thermal burns of the skin in acute radiation disease. Bull Exp Biol Med. 2004;138(3):311-5.

73. Gentile Pietro, Scioli Maria Giovanna, Bielli Alessandra et al. Comparing different nanofat procedures on scars: role of the stromal vascular fraction and its clinical implications. Regen Med. 2017;12:939-52.

74. Pietro G, Donato $C$, Enza $P$, et al. Engineered fat graft enhanced with adipose-derived stromal vascular fraction cells for regenerative medicine: clinical, histological and instrumental evaluation in breast reconstruction. $J$ Clin Med. 2019;8(4):504.

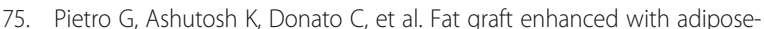
derived stem cells in aesthetic breast augmentation: clinical, histological, and instrumental evaluation. Aesthet Surg J. 2020:40:962-77.

76. Pietro G, Serena PM, Claudio C. Characteristics and potentiality of human adipose-derived stem cells (hASCs) obtained from enzymatic digestion of fat graft. Cells. 2019;8(3):282.

77. Pietro G, Simone G, Review C. Adipose-derived stem cells (ASCs) and adipocyte-secreted exosomal microRNA (A-SE-miR) modulate cancer growth and proMote wound repair. J Clin Med. 2019;8(6):855.

78. Pietro G, Barbara DA, Methap P, et al. Adipose-derived stromal vascular fraction cells and platelet-rich plasma: basic and clinical evaluation for cellbased therapies in patients with scars on the face. J Craniofac Surg. 2014;25: 267-72

79. Pietro $G$, Aris $S$, Jacopo $P$, et al. Research progress on mesenchymal stem cells (MSCs), adipose-derived mesenchymal stem cells (AD-MSCs), drugs, and vaccines in inhibiting COVID-19 disease. Aging Dis. 2020;11:1191-201.

80. Pietro G, Aris S. Adipose stem cells (ASCs) and stromal vascular fraction (SVF) as a potential therapy in combating (COVID-19)-disease. Aging Dis. 2020;11:465-9.

81. Pietro G, Aris S. Adipose-derived stromal stem cells (ASCs) as a new regenerative immediate therapy combating coronavirus (COVID-19)-induced pneumonia. Expert Opin Biol Ther. 2020;20:711-6.

82. Nandra K, Takahashi K, Collino M, Benetti E, Wong W, Goh F, Suzuki K, Patel $\mathrm{N}$, Thiemermann C. Acute treatment with bone marrow-derived mononuclear cells attenuates the organ injury/dysfunction induced by hemorrhagic shock in the rat. Shock. 2012;37(6):592.

83. Mao M. Intravenous delivery of bone marrow-derived endothelial progenitor cells improves survival and attenuates lipopolysaccharideinduced lung injury in rats. Shock. 2010;34:196-204.

84. Liu Y, Chen J, Zhang Z, Ma X, Chen Y, Du X, Liu H, Zong Y, Lu G. NLRP3 inflammasome activation mediates radiation-induced pyroptosis in bone marrow-derived macrophages. Cell Death Dis. 2017;8(2):e2579.

85. Liu D, Kong F, Yuan Y, Seth P, Xu W, Wang H, Xiao F, Wang L, Zhang Q, Yang $Y$, et al. Decorin-modified umbilical cord mesenchymal stem cells (MSCs) attenuate radiation-induced lung injuries via regulating inflammation, fibrotic factors, and immune responses. Int J Radiat Oncol Biol Phys. 2018;101(4):945-56.

86. Guo D, Zhu X, Li Q, Liu G, Ruan G, Pang R, Chen Y, Wang Q, Wang J, Liu J, et al. Efficacy and mechanisms underlying the effects of allogeneic umbilical cord mesenchymal stem cell transplantation on acute radiation injury in tree shrews. Cytotechnology. 2018;70(5):1-22.

87. Fang S, Xu C, Zhang Y, Xue C, Yang C, Bi H, Qian X, Wu M, Ji K, Zhao Y, et al. Umbilical cord-derived mesenchymal stem cell-derived Exosomal microRNAs suppress myofibroblast differentiation by inhibiting the transforming growth factor- $\beta / S M A D 2$ pathway during wound healing. Stem Cells Transl Med. 2016;5(10):1425-39.

88. Lee J, Choi K, Park J, Moon H, Choi G, Lee J, Suh E, Kim H, Eun S, Kim G, et al. Bisphenol A distribution in serum, urine, placenta, breast milk, and umbilical cord serum in a birth panel of mother-neonate pairs. Sci Total Environ. 2018;1(626):1494-501.

89. Wang R, Zhu C, Qiao P, Liu J, Zhao Q, Wang K, Zhao T. Experimental treatment of radiation pneumonitis with human umbilical cord mesenchymal stem cells. Asian Pac J Trop Med. 2014;7(4):262-6. 
90. Silva V, Hilly O, Strenov Y, Tzabari C, Hauptman Y, Feinmesser R. Effect of cell phone-like electromagnetic radiation on primary human thyroid cells. Int J Radiat Biol. 2016;92:107-15.

91. Narayanan S, Jetti R, Kesari K, Kumar R, Nayak S, Bhat P. Radiofrequency electromagnetic radiation-induced behavioral changes and their possible basis. Environ Sci Pollut Res Int. 2019;26(30):30693-710.

92. Xiang M, Yuan Y, Fan L, Li Y, Li A, Yin L, Scott M, Xiao G, Billiar T, Wilson M, et al. Role of macrophages in mobilization of hematopoietic progenitor cells from bone marrow after hemorrhagic shock. Shock. 2012;37:518-23.

93. Xuan W, Wang Y, Tang Y, Ali A, Hu H, Maienschein-Cline M, Ashraf M, et al, Cardiac progenitors induced from human induced pluripotent stem cells with cardiogenic small molecule effectively regenerate infarcted hearts and attenuate fibrosis. Shock. 2018;50:627-39.

94. Zhao Y, Wang J, Yano N, Zhang L, Wang H, Zhang S, Qin G, Dubielecka P, Zhuang S, Liu P. Irisin promotes cardiac progenitor cell-induced myocardial repair and functional improvement in infarcted heart. J Cell Physiol. 2019; 234(2):1671-81.

95. Qiao Z, Greven J, Horst K, Pfeifer R, Kobbe P, Pape H, Hildebrand F. Fracture healing and the underexposed role of extracellular vesicle-based crosstalk. Shock. 2018;49(5):486-96.

96. Altman A, Abdul K, Alt E, Butler C. Adipose tissue-derived stem cells enhance bioprosthetic mesh repair of ventral hernias. Plast Reconstr Surg. 2010;126(3):855-7.

97. Forsythe R, Xu D, Lu Q, Deitch E. Lipopolysaccharide-induced enterocytederived nitric oxide induces intestinal monolayer permeability in an autocrine fashion. Shock. 2002;17(3):180.

98. Xiu F, Jeschke M. Perturbed mononuclear phagocyte system in severely burned and septic patients. Shock. 2013;40(2):81-8.

99. Stewart F, Seemann I, Hoving S, Russellet N. Understanding radiationinduced cardiovascular damage and strategies for intervention. Clin Oncol (R Coll Radiol). 2013;25:617-24.

100. Laura B, John F, Jenny U, Coombs C, Zehir A, Ptashkin R, Berger M, Levine R, Fagin J. Radioactive iodine-related clonal hematopoiesis in thyroid cancer is common and associated with decreased survival. J Clin Endocrinol Metab. 2018;103(11):4216-23.

101. Tycho I, Joe C, Krijn V, Joost P, Maarten J, Pieter A, Eric B, Steven A. Nonsurgical stem cell delivery strategies and in vivo cell tracking to injured myocardium. Int J Cardiovasc Imaging. 2011;27(3):367-83.

102. Yang S, Chung C, Ayala A, Chaudry I, Wang P. Differential alterations in cardiovascular responses during the progression of polymicrobial sepsis in the mouse. Shock. 2002;17(1):55.

103. Ince E, Temiz A, Ezer S. Poorly understood and often miscategorized congenital umbilical cord hernia: an alternative repair method. Hernia. 2017; 21(3):449-54.

104. Fordyce A, Timms L, Stalder K, Tyler H. Short communication: the effect of novel antiseptic compounds on umbilical cord healing and incidence of infection in dairy calves. J Dairy Sci. 2018;101(6):5444-8.

105. Dabrowski F, Burdzinska A, Kulesza A, Sladowska A, Zolocinska A, Gala K, Paczek L, Wielgos M. Comparison of the paracrine activity of mesenchymal stem cells derived from human umbilical cord, amniotic membrane and adipose tissue. J Obstet Gynaecol Res. 2017;43(11):1758-68.

106. Maillacheruvu P, Engel L, Crum I, Devendra K, Eric S. From cord to caudate: characterizing umbilical cord blood stem cells and their paracrine interactions with the injured brain. Pediatr Res. 2018;83(1-2):205-13.

107. Shohara R, Yamamoto A, Takikawa S, Iwase A, Hibi H, Kikkawa F, Ueda M. Mesenchymal stromal cells of human umbilical cord Wharton's jelly accelerate wound healing by paracrine mechanisms. Cytotherapy. 2012; 14(10):1171-81.

108. Liu F, Luo X, Shen H, Dong J, Yang J. Using human hair follicle-derived keratinocytes and melanocytes for constructing pigmented tissueengineered skin. Skin Res Technol. 2011;17:373-9.

109. Shim W, Mehta A, Lim S, Zhang G, Lim C, Chua T. G-CSF for stem cell therapy in acute myocardial infarction: friend or foe? Cardiovasc Res. 2011; 89(1):20.

110. Wang J, Hauer-Jensen M. Neuroimmune interactions: potential target for mitigating or treating intestinal radiation injury. Br J Radiol. 2007;80(1):S41-8.

111. Ra J, Shin I, Kim S, Kang S, Kang B, Lee H, Kim Y, Jo J, Yoon E, Choi H, et al. Safety of intravenous infusion of human adipose tissue-derived mesenchymal stem cells in animals and humans. Stem Cells Dev. 2011;20(8): 1297-308.

\section{Publisher's Note}

Springer Nature remains neutral with regard to jurisdictional claims in published maps and institutional affiliations. 